\begin{tabular}{cc} 
Jurnal Pendidikan Fisika \\
https://journal.unismuh.ac.id/index.php/jpf \\
\hline
\end{tabular}

\title{
Development of Physics Learning Media Based-Mobile Learning Using Adobe Flash CS6 at Muhammadiyah University of Makassar
}

\author{
Andi Arie Andriani ${ }^{*}$, Ana Dhifaini Sultan, Salwa Rufaida, Nurfadilah \\ Physics Education Department, Muhammadiyah University of Makassar, Makassar, 90221, Indonesia \\ * Corresponding author: andiarie@ unismuh.ac.id
}

Received: December 28, 2020; Accepted: January 18, 2021; Published: January 30, 2021

\begin{abstract}
This research is motivated by the fact that physics learning content based on mobile learning can be accessed widely and most students have cellphones, but it has not been widely used to increase student enthusiasm in learning physics. Physics Learning Media Based on Mobile Learning is an effort to solve this problem. One of them is by Development of Physics Learning Media-Based Mobile Learning Using Adobe Flash CS6. This study aimed to determine the development of learning media products based on mobile learning using adobe flash CS6 and to examine the the feasibility of learning media based on mobile learning using Adobe Flash CS6 at Muhammadiyah University of Makassar. This type of research was a research and development starting from the defining stage (define), the design stage (design), and the development stage (develop). This mobile learning-based physics learning media was tested for validity by 2 experts of media, and tested for its effectiveness by 33 students. The results achieved were the m-learning media products that used the adobe flash CS6 application with validity criteria that were relevant, consistent and have practical usability, as well as effective implementation. These instructional media products can be used by teaching staff and students in higher education. as well as effective implementation. These instructional media products can be used by teaching staff and students in higher education. as well as effective implementation. These instructional media products can be used by teaching staff and students in higher education.
\end{abstract}

Keywords: adobe flash CS6, development, mobile learning, physics learning media

() 2021 Physics Education Department, Universitas Muhammadiyah Makassar, Indonesia.

\section{INTRODUCTION}

One of the alternative forms of learning during the Covid-19 pandemic is online learning. In practice, online learning requires the support of mobile devices, such as android cellphones, tablets and laptops which can be used to access information anywhere and anytime (Gikas \& Grant, 2013). The level of development of android mobile phones which is getting higher and relatively cheaper is a supporting factor for the increasing number of android mobile users in Indonesia.

Android-based learning media have the advantages of being easily accessible to anyone and anywhere. Mobile learning is the 
latest ICT advances in the education world where the mobile device is used as media containing a variety of material or teaching aid and can be used at school and home and also it is easier and lighter to bring (Hanafi \& Samsudin, 2012). Zheng et al. (2015) stated that the development of today's smartphones is growing rapidly and quickly, the technology is not only done by the user as a communication medium, but can be used also as a learning medium that is reliable and user friendly.

Furthermore, mobile learning is also flexible because it can be changed or updated at any time if there are some changes in material. In addition it can be used for selflearning, mobile learning can also be used as a learning medium that can be accessed anytime and anywhere (Douglas et al., 2008; Sarrab et al., 2012; Tamhane et al., 2015).

Anggaraeni in Astuti et al. (2017) stated that android is the most popular operating system in society because it has advantages, such as open source which gives developers the freedom to create applications. Android can be made and developed in an attractive manner to provoke a sense of interest from students to learn, so that students can more easily accept the material presented by the lecturer.

Based on observations of several physics students, it is known that student enthusiasm for learning is still low, because students tend to be passive when lecturers deliver materials. The instructor has never developed mobile learning media using adobe flash CS6, even though most students have androids.

Research that supports this research is research that has been conducted by Estianinur et al. (2017) which shows that the mobile learning application using Androidbased adobe flash CS6 is suitable for use as a learning medium that can be accessed anytime and anywhere.

According to Fatimah (2014), mobile learning media in the implementation of classroom learning has three functions, namely supplement, complement, and substitution. Furthermore, Bonaditya (2014) stated that adobe flash is a program specifically designed to create reliable and lightweight of two-dimensional animation, so that flash is widely used to build and provide interactive learning menu animation effects.

The research questions consist of how this study develops learning media products based on mobile learning using Adobe Flash CS6 and how it examines the feasibility of learning media based on mobile learning using Adobe Flash CS6 at Muhammadiyah University of Makassar. According to Ashari \& Istiyanto (2009), mobile learning is a learning approach that involves mobile devices such as mobile phones, laptops, and tablet PCs, where students can access materials, instructions and applications related to subjects without being limited by space and time.

Thus, this research aims to determine the development of learning media products 
based on mobile learning using adobe flash CS6 and to examine the feasibility of learning media based on mobile learning using adobe flash CS6 at Muhammadiyah University of Makassar.

\section{METHODS}

This type of research is a development research, using the Thiagarajan development model through the 4D-Model (define, design, develop, and disseminate). The four stages in the Thiagarajan 4D-Model (Trianto, 2007) are the stages in the development of instructional media, however this research will be adopted up to the third stage, namely the develop stage. This research was tested on students of physics class A which consisted of one class with a total of 33 people. The research was carried out in August 2020, at the Muhammmadiyah University in Makassar.

This research procedure was carried out in three stages, namely as follows:

\section{A. Preparation stage}

The preparation stage was making questionnaires and learning tools.

\section{B. Implementation stage}

The implementation stage was implementing physics learning using online learning media, observing student activities during the learning process and giving questionnaires to students and lecturers to find out responses to learning physics using media after the learning process.

\section{Data analysis stage}

The activity at this stage was to analyze the data collected during the implementation stage. The data analyzed were validation sheets, data from student activity observations, and student data.

The development stage in this study adopted a 4D type device development model with changes tailored to the needs of the research which included media production, validation from a team of experts, and media trials.

The data that had been collected using instruments were then analyzed quantitatively to determine the quality of the media produced. The data analyses used were as follows:

\section{1) Validity data analysis}

Validity data analysis was carried out on all learning media formats and all assessment data collection instruments. Validity was determined by matching the average total validity of all assessment items with the validity criteria, which were as follows:

a) Invalid (TV), if the total validity score: $1.0 \leq \overline{\mathrm{X}}<1.5$

b) Sufficiently Valid (CV), if the total validity score: $1.5 \leq \overline{\mathrm{X}}<2.5 \overline{\mathrm{X}}$

c) Valid (V), if the total validity score: $2.5 \leq \overline{\mathrm{X}}<3.5$

d) Very Valid (SV), if the total validity score: $3.5 \leq \overline{\mathrm{X}}<4$ 


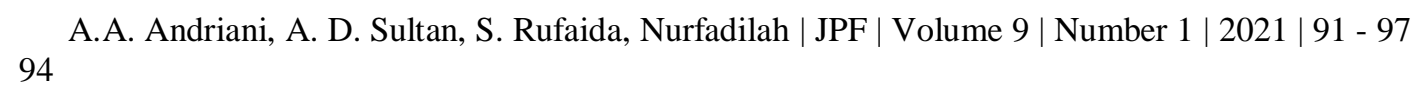

2) Analysis of questionnaire result response data

Student response data were obtained from the results of a questionnaire on the media in learning activities. The learning media developed met practical criteria if more than $50 \%$ of students responded positively to at least $70 \%$ of the number of aspects being asked.

\section{RESULTS AND DISCUSSION}

The product produced from this research is a mobile learning-based physics learning media using adobe flash CS6. This learning media product is made and designed by the researcher as a tool in the learning process. The aspects that are considered in validating learning media are aspects of appearance quality and attractiveness. The validation results from media experts can be seen in Table 1 below.

Table 1. Learning media validation results

\begin{tabular}{clcl}
\hline No. & $\begin{array}{l}\text { Assessment } \\
\text { aspects }\end{array}$ & $\overline{\mathbf{X}}$ & $\begin{array}{l}\text { Informatio } \\
\mathbf{n}\end{array}$ \\
\hline 1. & Display quality & 3.50 & Very valid \\
2. & Attractiveness & 3.37 & Valid \\
\hline Average rating & 3.43 & Valid \\
\hline
\end{tabular}

The total average value of validity on learning media is 3.43 . Based on the validity criteria, this value is included in the "valid" category because it is at $(2.5 \leq 3.5)$. If viewed from the two aspects above as a whole, the learning media of this model can be declared to meet the validity criteria. Furthermore, the results of the validation of the student response questionnaire can be seen in Table 2 below:

Table 2. Results of student response questionnaire validation

\begin{tabular}{clll}
\hline No. & $\begin{array}{l}\text { Assessment } \\
\text { aspects }\end{array}$ & $\overline{\mathbf{X}}$ & Information \\
\hline 1. & Instructions & 3 & Valid \\
2. & Language & 3.25 & Valid \\
3. & Contents & 3.25 & Valid \\
\hline Average rating & 3.16 & Valid \\
\hline
\end{tabular}

The total mean value of validity at student response questionnaire obtained 3.16. Based on the validity criteria, this value is included in the valid category because it is at $2.5 \leq 3.5$. If viewed from the three aspects above as a whole, the student response questionnaire can be declared to meet the validity criteria, so that it can be used in conducting research. The second validator's understanding (reliability) index of the student response questionnaire with an average of 0.80 or $80 \%$ has met the criteria for good reliability because it is greater than 0.75 or $75 \%$.

The results of the development of learning media can be seen in the image below

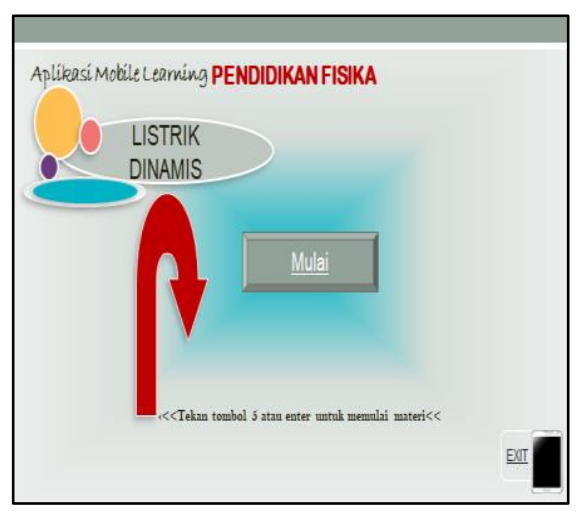

Figure 1. Main screen display 


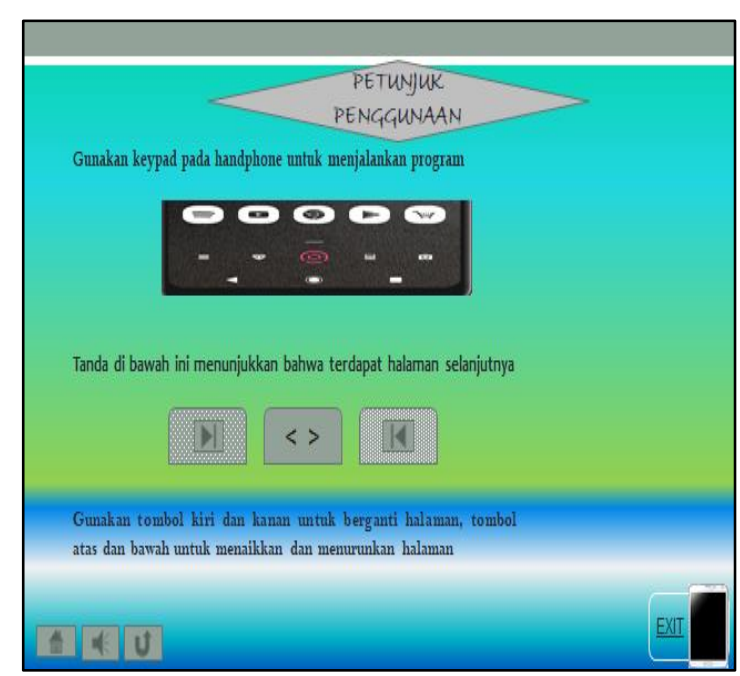

Figure 2. Display instructions for use

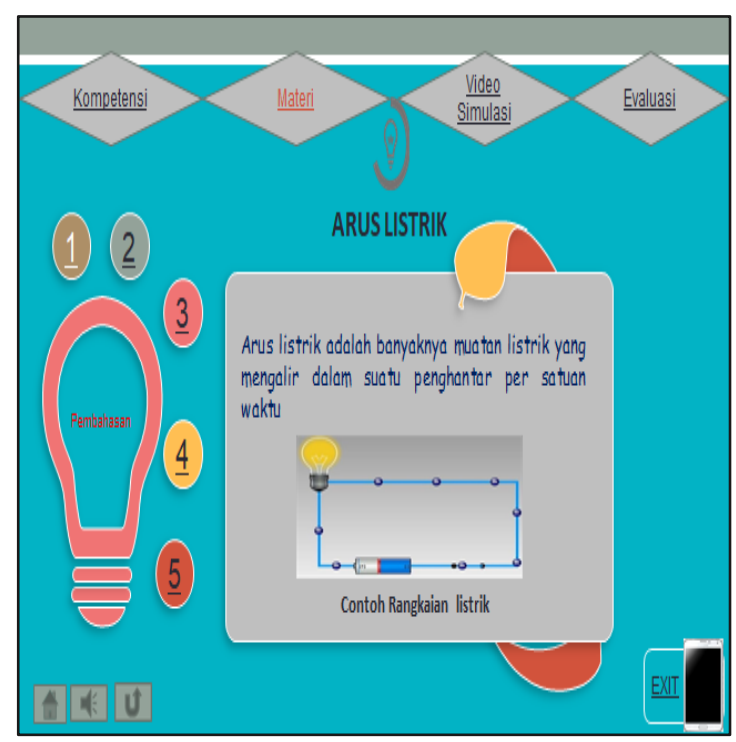

Figure 3. Material menu screen display

Mobile learning based learning media is made using adobe flash CS6 software with emulator specifications to run on a PC: Adobe device central CS6, Flash version: flash lite, dimensions: 240 x 320 pixels, content type: standalone player and memory after creation: $620 \mathrm{~kb}$. The dynamic electric material mobile learning display consists of the main screen display, the user manual screen display and the material screen display. The main menu of instructional media consists of competencies, materials, simulation and evaluation videos. Teachers and students can click on the material menu and subject matter 1-5 to view the contents.

This learning media is validated to instructional media experts, trials of Physics Education lecturers and student responses to the media created. This feasibility test was conducted to determine the quality level of the media made.

The results of this study are also in line with Nurwahid (2017) which stated that the results of educators and students' assessments of the learning media developed are positive. The response of educators is $80,65 \%$, which means that it is received positively, for the response of students is $80,47 \%$, which means that it is received positively. Furthermore, Bustomi (2010) research's result showed that the android-based learning applications can be used as the interactive learning media.

According to Ishaq (2013), the online system learning media is able to minimize the problems faced by students related to the learning process that is not optimal, including both results and processes, as well as inadequate support for facilities in an effort to support a learning process.

\section{CONCLUSION AND SUGGESTION}

Physics learning media based on mobile learning using adobe flash CS6 which was developed has met the valid criteria. The validator's assessment of the quality of 


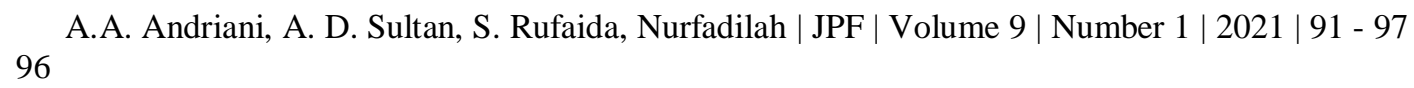

display and media attractiveness is practical based on the efficiency of learning and student responses, so it is appropriate to use as a sumer for learning physics.

The suggestions put forward are for the development of the next mobile learning application, it is hoped that it will be even better. Things that need to be developed again are the addition of more detailed simulations, examples of questions in the material section, making worksheets, adding video or audio.

\section{ACKNOWLEDGMENTS}

Thank you to the validators who are willing to take the time to provide assessments and input on physics learning media based on mobile learning using Adobe Flash CS6. As well as the Physics Education lecturers who were involved in this research.

\section{REFERENCES}

Astuti, I. A. D., Sumarni, R. A., Saraswati, D. L. (2017). Development of androidbased mobile learning physics learning media. Journal of Research and Development in Physics Education, 3(1), 57-62.

http://journal.unj.ac.id/unj/index.php/j pppf/article/view/2533/1948

Ashari, S., \& Istiyanto, J. E. (2009). Perspectives \& challenges of mobile learning development. Scientific Journal of Informatics, 5(1), 46-55. http://repository.maranatha.edu/337/1 /Perspektif\%20Tantangan\%20Penge mbangan\%20M-Learning luar.pdf
Bonaditya. (2014). Introduction to adobe flash CS6. Retrieved from https://id.wikipedia.org/wiki/Adobe $\underline{\text { Flash }}$

Bustomi, A. Y. (2010). Human senses learning application based on android. Journal of Telematics, 3(1), 25-30. https://ejournal.amikompurwokerto.a c.id/index.php/telematika/article/view $\underline{/ 195}$

Estianinur. (2017). Mobile learning application development using adobe flash professional CS6 based android on the characteristics of mechanical waves for class XI SMA. Journal of Physics Education, 2(2), 1-11. https://onlinejournal.unja.ac.id /EDP/article/view/4054/8541

Fatimah, S., \& Mufti, Y. (2014). Development of learning media for android-based smartphone sciencephysics as strengthening student character. Kaunia's Journal, 10(1), 59-64.

http://ejournal.uinsuka.ac.id/saintek/k aunia/article/view/1066

Gikas, J., \& Grant, M. M (2013). Mobile computing devices in higher education: Student perspectives on learning with cellphones, smartphones \& social media. Journal of Internet and Higher Education, 19 (2), 18-26.

https://daneshyari.com/ article/preview/357763.pdf

Hanafi, H. F., \& Samsudin, K. (2012). Mobile Learning Environment System (MLES): The case of android-based learning application on undergraduates learning. International Journal of Advanced Computer Science and Applications, 3(3), 1-5. https://arxiv.org/ftp/arxiv/papers/120 4/1204.1839.pdf 
Ishaq. (2013). Design of learning development based on information and communication technology (ICT) in computer application courses. Jurnal Pendidikan Fisika, 1(1), 73-85. https://journal.unismuh.ac.id/index.ph p/jpf/article/view/191/178

Mcconatha, D., Praul, M., Lynch, M. J. (2008). Mobile learning in higher education: an empirical assessment of a new educational tool. Turkish Online Journal of Educational Technology. 7(3), 223-244.

https://files.eric.ed.gov/fulltext/EJ110 2943.pdf

Nurwahid, S. (2017). Development of webbased science learning tutorial media for class VIII SMPN 5 Pallangga students. Jurnal Pendidikan Fisika 5(2), 156-174.

https://journal.unismuh.ac.id/index.ph p/jpf/article/view/621/667

Sarrab, M., Elgamel, L., Aldabbas, H. (2012). Mobile learning (M-Learning) and educational environments. International Journal of Distributed and Parallel Systems (IJDPS), 3(4), 31-38.

https://www.researchgate.net/publicat ion/262488863_Mobile_Learning_MLearning_and_Educational_Environ ments/link/54f4a2d60cf2eed5d7350c 68/download.

Tamhane, K.D, et al. (2015). Mobile learning application. International Journal of Scientific and Research Publications, 5(3), 1-4.

http://www.ijsrp.org/research-paper0315/ijsrp-p39128.pdf

Zhaohua, Z., Cheng, J., Peng, J. (2015). Design and implementation of teaching system for mobile crossplatform. International Journal of Multimedia and Ubiquitous Engineering, $\quad$ 10(2), 287-296. https://www.researchgate.net/publicat ion/283445029_Design_and_Implem entation_of_Teaching_System_for_M obile Cross-platform

Trianto. (2007). Integrated Learning Model in Theory and Practice. Jakarta: Prestasi Pustaka Publisher. 